and when published reports are so phrased as to make explicit reference of observed items to their proper class, and explicit statement that such and such elements were not determined.

W. M. D.

\section{JAMES CARROLL}

MaJor James Carroll, Surgeon U. S. A., died at his home in the city of Washington on September 16, after an illness of about seven months.

Major Carroll was born in England June 5, 1854. When about fifteen years of age he emigrated to this country, and on June 9, 1874, enlisted in the United States army, and served as private, corporal, sergeant and hospital steward from that date to May 21, 1898, when he was appointed an acting assistant surgeon.

While still a soldier he began the study of medicine at the University of the City of New York during the session 1886-7. After a break of a year he resumed his medical studies in Baltimore at the University of Maryland, 1889-91, and received his degree from that institution.

$\mathrm{He}$ was appointed first lieutenant, assistant surgeon, in the medical corps, October 27, 1902 , and promoted to the grade of majorsurgeon, by special act of congress March 2, 1907 , on account of his services in connection with the discovery of the mode of transmission of yellow fever, and the courage shown by him in subjecting himself to experiment with a view to demonstrating the method of transmission by a mosquito.

Doctor Carroll's was the first experimental case of yellow fever. He suffered a very severe attack to which he attributed a heart trouble, which finally caused his death.

Doctor Carroll's interest in the subject of yellow fever did not cease with the discovery of the method of its transmission, but he continued to make many independent contributions to the literature on the subject.

The Havana Yellow Fever Commission, appointed upon the recommendation of Surgeon General Sternberg, U. S. A., in 1900, consisted of Major Walter Reed, Surgeon, U. S.
A.; Dr. James Carroll, Dr. Jesse W. Lazear and Dr. A. Agramonte. The death of Dr. Carroll leaves Dr. Agramonte, a Cuban physician, as the only surviving member of the commission.

The bacteriological and experimental investigations of the commission were to a large extent conducted by Dr. Carroll. During Major Reed's absence in the United States the inoculations by means of infected mosquitoes were begun.

On August 11, 1900, Dr. Lazear made the first experiment, but nine distinct inoculations on persons, including himself and Acting Assistant Surgeon A. S. Pinto, were unsuccessful. We know now that these failures were due to two facts-first, that patients after the third day of the disease can not convey the infection to the mosquito, and second, that after having bitten a yellow-fever case the mosquito can not transmit the disease until after an interval of at least twelve days. On August 27 a mosquito was applied to Dr. Carroll which happened to fulfil both of these conditions. The result was a very severe attack of yellow fever in which for a time his life hung in the balance.

$$
\text { G. M. S. }
$$

\section{SCIENTIFIC NOTES AND NEWS}

The Silliman lectures by Professor William Bateson will be given in the Peabody Museum at Yale University on October 8 and the following days. The subject of the course is "The Problems of Genetics."

The Herter Lectures before the Medical Department of the Johns Hopkins University will be given this session by Edward A. Schäfer, LL.D., F.R.S., professor of physiology in the University of Edinburgh, at the end of April, 1908. The Turnbull Lectures on poetry will be delivered by Professor A. V. Williams Jackson, of Columbia University, on Persian Poetry, probably in February.

Professor Otto Pfleiderer, of the University of Berlin, began a series of six lectures. in German on "The German Philosophy of Religion," at Harvard University, on September 30 . 